Gut, 1982, 23, 42-48

\title{
Enteropathy of coeliac disease in adults: increased number of enterochromaffin cells in the duodenal mucosa
}

\author{
K SJÖLUND,* J ALUMETS, N-O BERG, R HÅKANSON, AND F SUNDLER \\ From the Departments of Internal Medicine, Histology, Pathology and Pharmacology, \\ University of Lund, Lund, Sweden
}

SUMMARY Twenty-nine adult patients with coeliac disease and 39 patients with a normal duodenal morphology were studied with respect to the 5-HT containing enterochromaffin cells. Their number in duodenal biopsies was assessed by fluorescence histochemistry and they were examined by immunohistochemistry for peptides known or believed to occur in enterochromaffin cells. Antisera used were raised against substance $P$, motilin, and leu-enkephalin. In addition, the concentration of 5-HT was determined chemically. In adult coeliac disease there was a significant increase in the number of duodenal enterochromaffin cells compared with the control group. The concentration of 5-HT in the duodenal mucosa was also greatly increased. Substance P was found in a minority population of enterochromaffin cells. These cells were very few and did not increase in number in coeliac disease. Motilin cells were distinct from enterochromaffin cells. No enkephalin immunoreactive cells were found in the biopsies.

The intestinal mucosa is rich in 5-hydroxytryptamine (5-HT)-storing enterochromaffin cells. They comprise several subpopulations, distinguishable by the ultrastructure of their secretory granules and by their content of different peptides. Thus, immunoreactive substance $P$ and enkephalin have been shown to occur in separate populations of enterochromaffin cells. ${ }^{1-7}$ Also motilin has been claimed to occur in enterochromaffin cells, ${ }^{8-13}$ although today most authors seem to agree that cells storing authentic motilin are non-enterochromaffin. ${ }^{14-16}$

Coeliac disease is accompanied by a raised output of 5-hydroxyindoleacetic acid in urine ${ }^{1718}$ and by increased concentrations of 5-HT in plasma. ${ }^{19}$ Challacombe et al. ${ }^{20}$ reported raised concentrations of 5-HT in the duodenal mucosa in seven children and four adults with coeliac disease. In 10 children with coeliac disease there was an increased number of duodenal enterochromaffin cells. ${ }^{21}$ As earlier studies included only few adults we decided to reinvestigate this feature of coeliac disease in adult patients. In addition, we have examined duodenal biopsies for the presence of peptides known or believed to occur in

*Address for correspondence: Dr K Sjollund, Department of Internal Medicine, University Hospital, 22185 Lund, Sweden.

Received for publication 21 May 1981
5-HT-storing enterochromaffin cells by immunohistochemistry using antisera against substance $P$, motilin, and enkephalin.

\section{Methods}

TISSUE MATERIAL

Biopsies were obtained from the mucosa of the most distal part of the duodenum (at the ligament of Treitz) using a large size Watson capsule. Biopsies were taken from 29 patients with coeliac disease (19 females and 10 males; median age 41 years, range $19-53$ years). For conventional histology the sections were stained with haematoxylin-eosin and the enteropathy was graded according to Alexander ${ }^{22}: 16$ had flat mucosa, four convoluted mucosa, and nine ridging of villi; 18 of the patients had a gluten-free diet (Table 1). The control

Table 1 Classification of patients with coeliac disease

\begin{tabular}{lrlll}
\hline Enteropathy & Number & $\begin{array}{l}\text { Gluten free diet } \\
\text { number }\end{array}$ & \multicolumn{1}{l}{ Age $(y r)$} & \\
\cline { 4 - 5 } & & & Median & Range \\
\hline Flat mucosa & 16 & 5 & 38 & $25-53$ \\
Convoluted mucosa & 4 & 4 & 42 & $41-44$ \\
Ridging of villi & 9 & 9 & 30 & $19-53$ \\
Total number & 29 & 18 & & \\
\hline
\end{tabular}


Table 2 Composition of control group

\begin{tabular}{lcll}
\hline $\begin{array}{l}\text { Symptoms causing } \\
\text { examinations }\end{array}$ & Number & Age $(y r)$ & \\
\cline { 2 - 4 } & & Median & Range \\
\hline Diarrhoea & 10 & 36 & $21-60$ \\
Flatulence & 8 & 31 & $17-46$ \\
Abdominal pain & 7 & 41 & $24-64$ \\
Liver dysfunction & 7 & 35 & $22-59$ \\
Iron deficiency & 3 & 22 & $20-67$ \\
Proctitis & 2 & 26 & $23-29$ \\
Constipation & 1 & 46 & - \\
Weight loss & 1 & 25 & - \\
Total number & 39 & 35 & $17-67$ \\
\hline
\end{tabular}

group comprised 39 patients with various abdominal disturbances (Table 2) but having a normal mucosal morphology ( 22 females and 17 males; median age 35 years, range 17-67 years). Thorough gastrointestinal examination, including radiography and absorptive function tests, revealed no abnormalities.

The biopsies were placed on millipore filters and cut perpendicular to the mucosal surface. The biopsy was cut in two pieces, one for histochemistry, the other for chemical determination of 5-HT. Generally, the biopsies were too small to allow assessment of their wet weight. Only one biopsy was taken from each patient.

\section{HISTOCHEMISTRY}

The specimens were frozen to the temperature of liquid nitrogen in a propane-propylene mixture and freeze-dried. They were then exposed to gaseous formaldehyde for one hour at $80^{\circ} \mathrm{C}^{23}$ and embedded in paraffin in vacuo. Sections were cut at $5 \mu \mathrm{m}$ and placed on albumin-coated glass slides. Formaldehyde vapour fixation induced strong fluorescence in the enterochromaffin cells. ${ }^{23}$ For immunohistochemistry (the PAP technique of Sternberger ${ }^{24}$ ) sections were deparaffinised in xylene, hydrated, and exposed to one of the antisera (Table 3 ) for 24 hours at $4^{\circ} \mathrm{C}$. The site of the antigen-antibody reaction was revealed by incubation with unlabelled goat anti-rabbit IgG (SBL,
Stockholm, Sweden) (diluted 1:30) followed by incubation with peroxidase-anti-peroxidase (PAP) complex (diluted 1:160). PAP was purchased from Cappel Laboratories, Downington, Pennsylvania, USA. All solutions contained $0 \cdot 25 \%$ human serum albumin and $0.25 \%$ Triton-X-100. The sections were dehydrated, mounted in Permount, and examined by light microscopy. Conventional staining controls included deletion of the first antiserum, deletion of the second antiserum, and deletion of both antisera. As specificity controls served sections exposed to antisera which had been inactivated by incubation for 24 hours with synthetic antigen $(10-100 \mu \mathrm{g} / \mathrm{ml}$ diluted antiserum) before application in immunocytochemistry (absorption controls). In addition, the antisera were tested for cross-reactivity with a variety of peptides (as specified in Table 3) by preincubation for 24 hours with $100 \mu \mathrm{g}$ of the respective peptide per $\mathrm{ml}$ antiserum. For identification, the fluorescent enterochromaffin cells in the sections were photographed and the sections were subsequently subjected to immunohistochemistry.

\section{ANTISERA}

Details are given in Table 3. Sustance $P$ antisera are directed against the $\mathrm{C}$-terminal end and cross-react with other tachykinins. ${ }^{25}$ Antiserum K 16 in addition cross-reacts with bombesin. The leu-enkephalin antiserum cross-reacts with met-enkephalin but not with $\beta$-endorphin. ${ }^{72}$ One of the motilin antisera $(123 / \mathrm{M} 4)$ is directed against the entire motilin sequence, whereas the other three are directed against the C-terminal portion. ${ }^{11} 27$

\section{DETERMINATION OF 5-HT}

The specimens were placed in $2 \mathrm{ml} 80 \%$ aqueous acetone and stored for a few days at $4^{\circ} \mathrm{C}$ in order to extract 5-HT. The acetone extract was evaporated to dryness under reduced pressure. The dry residue was taken up in $2 \times 2 \mathrm{ml}$ acidified $\mathrm{n}$-butanol $(0.1 \mathrm{ml}$ concn $\mathrm{HCl}$ in $100 \mathrm{ml} \mathrm{n}$-butanol) and 5-HT was transterred to

Table 3 Details of antisera

\begin{tabular}{|c|c|c|c|c|}
\hline Antigen & $\begin{array}{l}\text { Antiserum } \\
\text { code no. }\end{array}$ & $\begin{array}{l}\text { Working dilution, } \\
\text { immunoperoxidase (PAP) } \\
\text { staining }\end{array}$ & Source & References \\
\hline Substance $P$ & $\begin{array}{l}\text { K } 16 \\
\text { JK } 1\end{array}$ & $\begin{array}{l}1 / 80 \\
1 / 640\end{array}$ & G Nilsson, Uppsala, Sweden & 33 \\
\hline Motilin & $\begin{array}{l}\text { GP } 1103 \\
\text { R } 1105 \\
\text { MBR-01-6 } \\
123 / M 4\end{array}$ & $\begin{array}{l}1 / 5120 \\
1 / 280 \\
1 / 640 \\
1 / 1000\end{array}$ & $\begin{array}{l}\text { N Yanaihara, Shizuoka, Japan } \\
\text { J Polak, London, England }\end{array}$ & $\begin{array}{l}27 \\
27 \\
27 \\
11\end{array}$ \\
\hline Enkephalin & "Leu-enk" & $1 / 240$ & $\begin{array}{l}\text { K J Chang. Wellcome Research } \\
\text { Lab., New Jersey, USA. }\end{array}$ & 26 \\
\hline
\end{tabular}

The following peptides were tested for cross-reactivity of the above antisera; $K$ 16, JK 1-bombesin, enkephalin physalaemin, somatostatin, vasoactive intestinal peptide (VIP). GP 1103, R 1105, MBR-01-6. 123/M4-cholecystokinin (CCK), gastrin, glucagon, secretin, Leu-enk- $\beta$-endorphin, $\beta$-lipoprotein, met-enkephalin, somatostatin, substance $P$, VIP. 


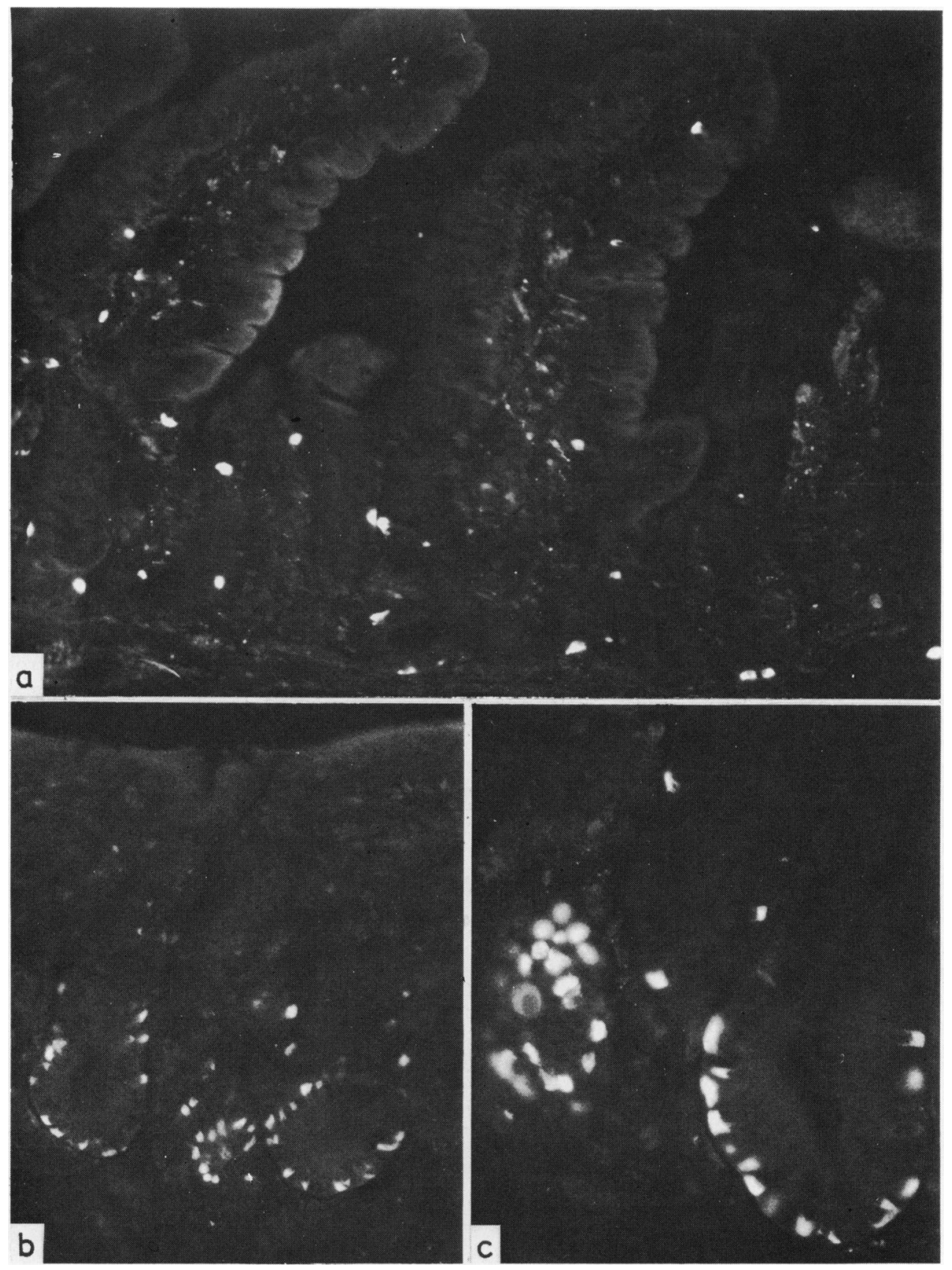

Fig. 1 Fluorescence micrographs showing enterochromaffin cells in duodenal mucosa. (a) Scattered cells in a control patient. $\times 200$. (b) Numerous cells in the crypts in coeliac disease (flat mucosa). $\times 200$. (c) High magnification micrograph showing a cluster of enterochromaffin cells in the basal portion of a crypt in coeliac disease. $\times 400$. 
an aqueous phase by shaking with $1.5 \mathrm{ml} 0.1 \mathrm{~N} \mathrm{HCl}$ and $6 \mathrm{ml} \mathrm{n}$-heptane. The recovery of 5-HT in this procedure (tested by external and internal standards) was better than $90 \%$. 5-HT was determined fluorometrically by its reaction with o-phthalaldehyde. ${ }^{28}$ The 5-HT content was correlated to the dry weight of the acetone-extracted residue and to the amount of soluble protein in the acetone-extracted residue after homogenisation in $1 \mathrm{ml} 0.1 \mathrm{M}$ phosphate buffer, $\mathrm{pH} 7.0$ and centrifugation at $15000 \times \mathrm{g}$. Protein was determined ${ }^{29}$ on aliquots of the supernatant.

\section{CALCULATIONS AND STATISTICAL ANALYSIS}

The fluorescence and the light microscope had a $\times 10$ objective and a $\times 12.5$ eyepiece (visual field diameter $1.4 \mathrm{~mm}$ ). Cells were counted in 15-30 randomly selected fields in sections cut perpendicular to the mucosal surface and showing the entire height of the mucosa. ${ }^{30}$ Cell counts were expressed as number of cells per unit length of mucosa $(1.2 \mathrm{~mm})$. The tissue concentrations of 5-HT were expressed as ng free base per $\mathrm{mg}$ dry weight or $\mathrm{mg}$ soluble protein. The recorded values had a skewed distribution and they were therefore $\log$ transformed resulting in a normal distribution. Statistical significance was assessed by Student's $t$ test.

\section{Results}

In the duodenal mucosa of controls enterochromaffin cells occurred scattered with some predominance in the crypts (Fig. 1a). In coeliac disease enterochromaffin cells were numerous and were restricted to the basal portion of the crypts (Fig. 1b). Often the cells had a patchy distribution, sometimes occurring in clusters, reminiscent of microadenomas (Fig. 1c). No

Enterochromaffin cells $\quad 5$-Hydroxytryptamine concentration

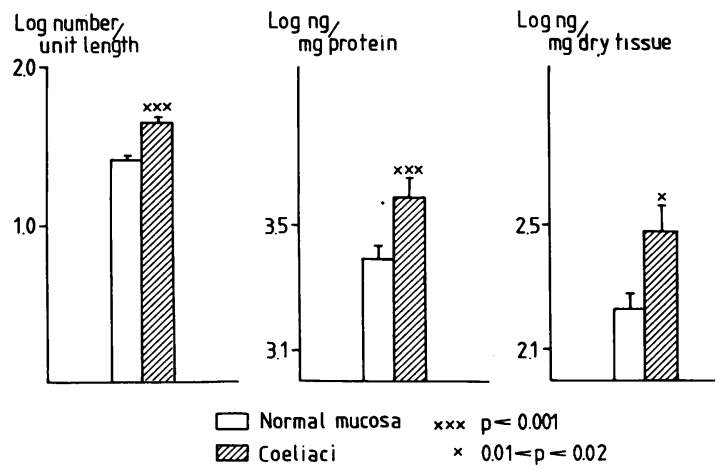

other cells or structures in the biopsies displayed 5-HT fluorescence.

In the whole group of patients with coeliac disease there was a $73 \%$ increase $(P<0.001)$ in the number of enterochromaffin cells per unit length (mean: 44.6) compared with the control group (mean: 25.8) (Fig. 2). In the patients with the most severe form of the disease (flat mucosa) the increase was $100 \%$ (mean: 52.1) $(\mathrm{P}<0.001)$. The number of crypts per unit length was the same in control patients and in the patients with coeliac disease (13.2 versus 13.5$)$. The 5 -HT concentration was much higher in the patients with coeliac disease than in the control group (Fig. 2). The increase was $76 \%(\mathrm{P}<0.02)$ when expressed in terms of $\mathrm{ng} / \mathrm{mg}$ dry weight (mean values 301 versus $170)$ and $100 \%(P<0.001)$ when expressed in terms of $\mathrm{ng} / \mathrm{mg}$ soluble protein (mean values: 4950 versus $2475)$. The amount of soluble protein $(\mu \mathrm{g} / \mathrm{mg}$ dry weight) did not differ significantly between the patients with coeliac disease and the control group (71 versus 77).

The increase in enterochromaffin cell number seemed to be related to the degree of enteropathy, whereas the 5-HT concentration was not (Table 4). No correlation was found between the number of enterochromaffin cells and the tissue concentration of 5-HT in the individual patients (Fig.3).

The substance $P$ antisera demonstrated very few immunoreactive cells, which were found to be identical with 5-HT storing enterochromaffin cells (Fig.4). The substance $P$ cells were too few to quantify. From visual inspection alone there was no overt difference in their number between controls and patients with coeliac disease. Scattered immunoreactive nerve fibres were seen in the lamina propria.

The motilin antisera demonstrated a fair number of endocrine cells which were non-enterochromaffin
Fig. 2 The log mean frequence of enterochromaffin cells in normal mucosa and in coeliac disease (left). The log mean concentration of 5-HT in $n g$ per mg soluble protein and per $\mathrm{mg}$ dry tissue from normal duodenum and from coeliac disease (right). Vertical lines give SEM. 
Table 4 Number of enterochromaffin cells and 5-HT concentration in duodenal biopsies in relation to degree of enteropathy

\begin{tabular}{|c|c|c|c|}
\hline Enteropathy & Enterochromaffin cells & $5-H T$ & $5-H T$ \\
\hline & number/unit length & ng/mg dry tissue & $n g / m g$ soluble protein \\
\hline $\begin{array}{l}\text { Normal mucosa } \\
\text { Ridging of villi } \\
\text { Flat to convoluted mucosa }\end{array}$ & $\begin{array}{l}25 \cdot 8 \\
35 \cdot 1 t \\
49 \cdot 9 \ddagger\end{array}$ & $\begin{array}{l}170 \\
360^{*} \\
277\end{array}$ & $\begin{array}{l}2475 \\
5180 \ddagger \\
4700+\end{array}$ \\
\hline
\end{tabular}

$* \mathrm{P}<0.05 . \quad+\mathrm{P}<0.01 . \quad \ddagger \mathrm{P}<0.001$.

\section{Log ng 5-HT/mg protein}

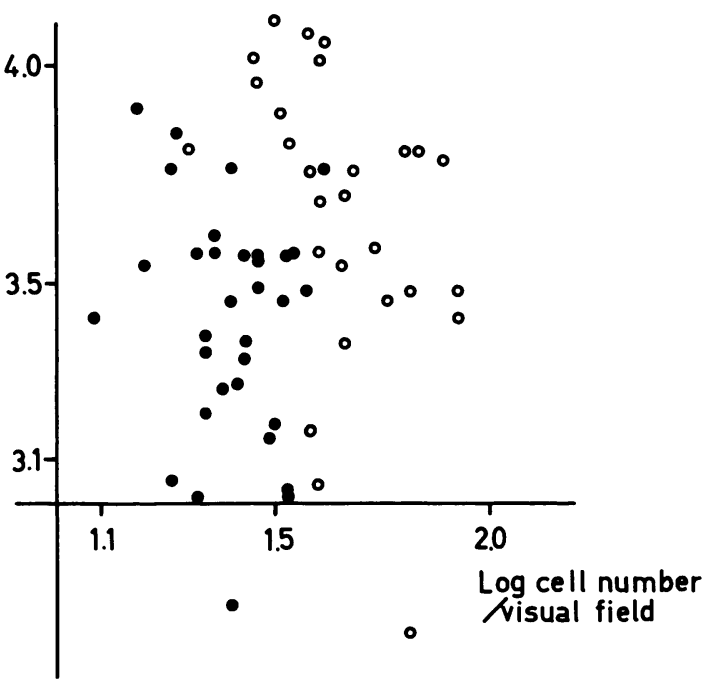

Fig. 3 The correlation between the log number of enterochromaffin cells and the log concentration of 5-HT in $\mathrm{ng} / \mathrm{mg}$ protein in the individual biopsies. enormal mucosa. Ocoeliac disease. Sixty of the 68 patients are represented. Eight samples taken for 5-HT determination were lost.
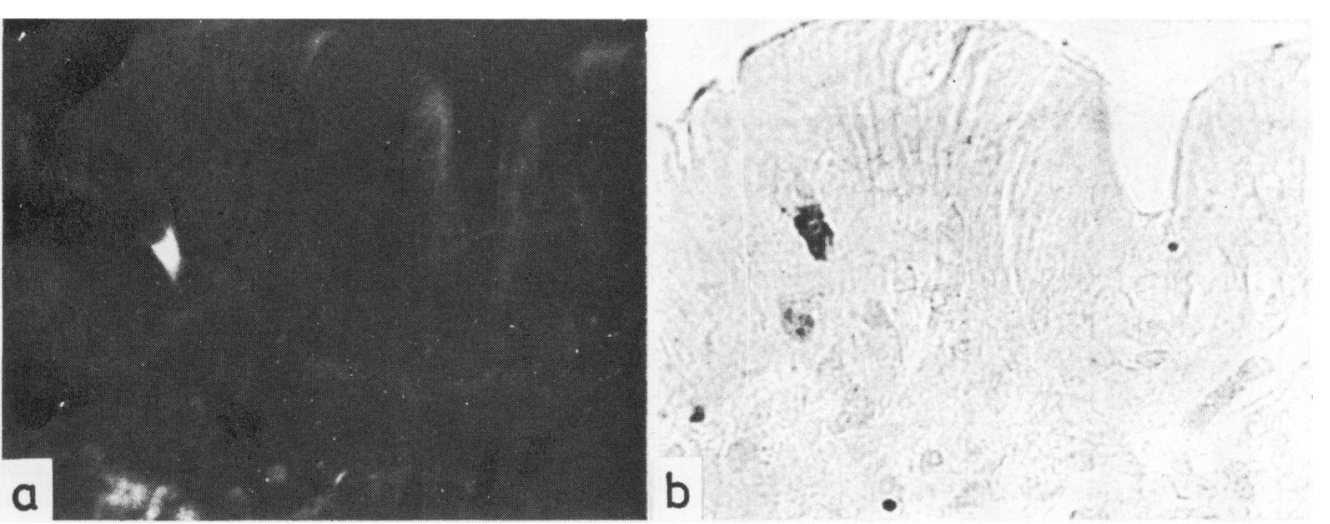

Fig. 4 Formaldehyde-induced 5-HT fluorescence in an enterochromaffin cell (a). The same section stained with antiserum against substance $P(K$ 16) (immunoperoxide staining) (b). The immunoreactive cell is identical with the one containing 5-HT. $\times 450$. 


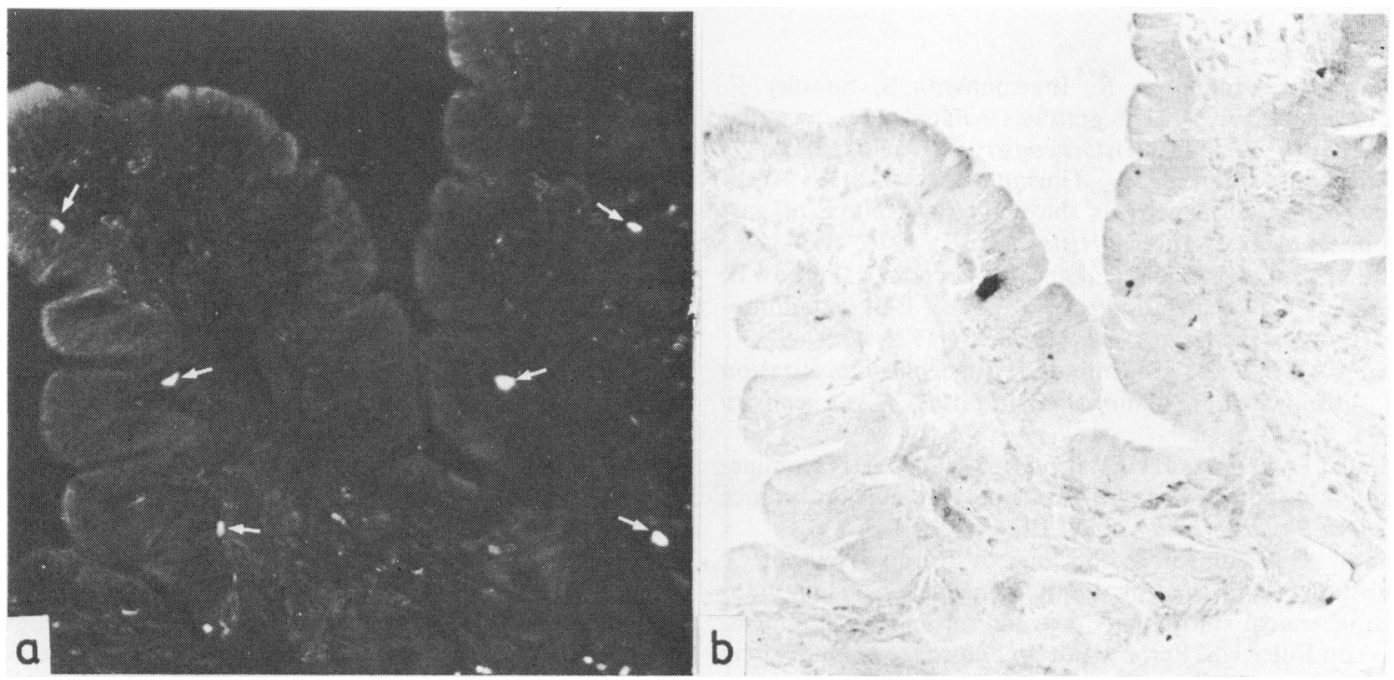

Fig. 5 Formaldehyde-induced 5-HT fluorescence in enterochromaffin cells (a) (arrows). The same section stained with motilin antiserum (123/M 4) (immunoperoxidase staining) (b). The motilin cell is distinct from the enterochromaffin cells. $\times 200$.

(Fig. 5). In specimens from patients with coeliac disease the motilin cells were increased in number as previously described. ${ }^{30}$

No endocrine cells could be demonstrated with the enkephalin antiserum.

\section{Discussion}

Coeliac disease in adult patients is associated with a marked proliferation of certain endocrine cell types, including somatostatin, gastric inhibitory peptide (GIP), cholecystokinin (CCK), motilin, and glucagon immunoreactive cells. ${ }^{30}$ The present study also revealed an increased number of the enterochromaffin cells and increased mucosal concentrations of 5-HT in such patients. These latter findings are in agreement with those of Challacombe et al. ${ }^{2021}$ in children with coeliac disease. However, there was no correlation between the number of enterochromaffin cells and the 5-HT concentration in the individual biopsy specimens. Perhaps there are other sources of 5-HT in the intestinal mucosa besides the enterochromaffin cells-for instance, nerve fibres and mast cells. In fact, Kumar et al. ${ }^{31}$ recently showed a large increase in the number of mast cells in coeliac disease. However, mast cells in our specimens failed to give formaldehydeinduced fluorescence (see also ${ }^{32}$ ) and, moreover, 5-HT in nerve fibres could not be demonstrated. Possibly, therefore, the 5-HT content differs from one enterochromaffin cell to another.
Earlier studies have shown that immunoreactive substance $P$ occurs in 5-HT containing enterochromaffin cells. ${ }^{1-6}$ This was confirmed in the present study. The number of enterochromaffin cells containing immunoreactive substance $P$ was very low and did not seem to increase in coeliac disease.

The motilin antisera demonstrated endocrine cells distinct from those containing 5-HT. This conflicts with previous findings from one laboratory ${ }^{8-13}$ but is in agreement with several other recent reports. ${ }^{14-16}$ It has been suggested that immunoreactive motilin may comprise a family of chemically related peptides. ${ }^{11}$ The present results do not exclude the possibility that motilin-like peptides may be present in enterochromaffin cells, although it can be concluded that autheritic motilin is not stored in such cells.

Immunoreactive enkephalin has previously been found to occur in enterochromaffin cells-for example, in the porcine duodenum. ${ }^{6}$ Such cells do not seem to occur in the human duodenal mucosa.

In conclusion, there is an increased number of duodenal 5-HT-containing enterochromaffin cells in coeliac disease. This increase does not seem to involve those enterochromaffin cells that store immunoreactive substance $P$.

This investigation was supported by grants from Förenade Liv Mutual Group Life Insurance Company, Stockholm, Sweden, the Swedish Medical Research Council (04X-4499, 04X-1007), and Albert Påhlsson's Foundation, Malmö, Sweden. 


\section{References}

'Alumets $J$, Håkanson $R$, Ingemansson $S$, Sundler $F$. Substance $P$ and 5-HT in granules isolated from intestinal argentaffin carcinoid. Histochemistry 1977; 52:217-22.

${ }^{2}$ Heitz Ph, Polak JM, Timson CM, Pearse AGE. Enterochromaffin cells as the endocrine source of gastrointestinal substance P. Histochemistry 1976; 49:343-7.

${ }^{3}$ Nilsson G, Larsson L-I, Hảkanson R, Brodin E, Pernow B, Sundler F. Localization of substance P-like immunoreactivity in mouse gut. Histochemistry 1975; 43:97-9.

${ }^{4}$ Pearse AGE, Polak JM. Immunocytochemical localization of substance $\mathbf{P}$ in mammalian intestine. Histochemistry 1975; 41:373-5.

'Sundler F, Alumets J, Håkanson R. 5-Hydroxytryptaminecontaining enterochromaffin cells: storage site of substance P. Acta Physiol Scand (Suppl) 1977; 452:121-3.

'Sundler F, Håkanson R, Larsson L-I, Brodin E, Nilsson G. Substance $P$ in the gut: immunochemical and immunohistochemical study of its distribution and development. In: von Euler US, Pernow B, eds. Substance P. New York: Raven Press, 1977:59-65.

${ }^{7}$ Alumets J, Håkanson R, Sundler F, Chang K-J. Leuenkephalin-like material in nerves and enterochromaffin cells in the gut. Histochemistry 1978; 56:187-96.

${ }^{8}$ Heitz Ph, Kasper M, Krey G, Polak JM, Pearse AGE. Immunoelectroncytochemical localization of motilin in human duodenal enterochromaffin cells. Gastroenterology 1978; 74:713-7.

9Pearse AGE. The cellular origin of motilin in the gastrointestinal tract. Scand J Gastroenterol 11 (Suppl) 1976; 39:35-8.

${ }^{10}$ Pearse AGE, Polak JM, Bloom SR, Adams C, Dryburgh JR, Brown JC. Enterochromaffin cells of the mammalian small intestine as the source of motilin. Virchovs Arch B Cell Pathol 1974; 16:111-20.

"Polak JM, Buchan AMJ, Dryburgh JR, Christofides N, Bloom SR, Yanaihara N. Immunoreactive motilins. Lancet 1978; 1:1364.

${ }^{12}$ Polak JM, Heitz Ph, Pearse AGE. Differential localization of substance $\mathrm{P}$ and motilin. Scand J Gastroenterol 11 (Suppl) 1976; 39:39-42.

${ }^{13}$ Polak JM, Pearse AGE, Heath CM. Complete identification of endocrine cells in the gastrointestinal tract using semithin sections to identify motilin cells in human and animal intestine. Gut 1975; 16:225-9.

${ }^{14}$ Forssman WG, Yanaihara N, Helmstaedter V, Grube D. Differential demonstration of the motilin cell and the enterochromaffin cell. Scand J Gastroenterol 11 (Suppl) 1976; 39:43-5.

${ }^{15}$ Helmstaedter V, Kreppein W, Domschke W, Mitznegg P, Yanaihara N, Wünsch E, Forssmann WG. Immunohistochemical localization of motilin in endocrine nonenterochromaffin cells of the small intestine of humans and monkey. Gastroenterology 1979; 76:897-902.

${ }^{16}$ Sundler F, Alumets J, Håkanson R, Sjölund K, Yanaihara N. Motilin and carcinoid tumours. Lancet 1978; 1:1101.

${ }^{17}$ Challacombe DN, Brown GA, Black SC, Storrie MH.
Increased excretion of 5-hydroxyindoleacetic acid in urine of children with untreated coeliac disease. Arch Dis Childh 1972; 47:442-5.

${ }^{18}$ Haverback BJ, Davidson JD. Serotonin and the gastrointestinal tract. Gastroenterology 1958; 35:570-8.

${ }_{19}$ Pimparker BD, Senesky D, Kasiel M. Bold serotonin in nontropical sprue. Gastroenterology 1961; 40:504-6.

${ }^{20}$ Challacombe DN, Dawkins PD, Baker P. Increased tissue concentrations of 5-hydroxytryptamine in the duodenal mucosa of children with coeliac disease. Gut 1977; 18:373-6.

${ }^{21}$ Challacombe DN, Robertson K. Enterochromaffin cells in the duodenal mucosa of children with coeliac disease. Gut 1977 ; 18:373-6.

${ }^{22}$ Alexander JO. The small intestine. In: Dermatitis herpetiformis, major problems in dermatology. London: Saunders 1975; 4:326.

${ }^{23}$ Björklund A, Falck B, Owman Ch. Fluorescence microscopic and microspectrofluorometric techniques for the cellular localization and characterization of biogenic monoamines. In: Rall JE, Kopin IJ, eds. Methods of investigative and diagnostic endocrinology: the thyroid and biogenic amines. Amsterdam: North Holland, 1972; 1:318-63.

${ }^{24}$ Sternberger LA. Immunocytochemistry. New Jersey: Prentice Hall, 1974.

${ }^{25}$ Brodin E, Alumets J, Håkanson R, Leander S, Sundler F. Immunoreactive substance $P$ in chicken gut. Distribution, development and possible functional significance. Cell Tiss Res 1981; 216:455-69.

${ }^{26}$ Miller RJ, Chang K-J, Cooper B, Cuatrecasas P. Radioimmunoassay and characterization of enkephalins in rat tissues. J Biol Chem 1978; 253:531-8.

${ }^{27}$ Yanaihara N, Sato H, Yanaihara C, et al. Characterization of various antisera against synthetic porcine motilin. Scand J Gastroenterol 1978; 13 Suppl 49:195.

${ }^{28}$ Maickel RP, Cox RH, Saillant J, Miller FP. A method for the determination of serotonin and norepinephrine in discrete areas of rat brain. Int J Neuropharmacol 1968; 7:275-81.

${ }^{29}$ Lowry OH, Rosenbrough NJ, Farr RJ, Randall RJ. Protein measurement with the Folin phenol reagent. Biol Chem $1951 ; 193: 265-75$.

${ }^{30}$ Sjölund K, Alumets J, Berg NO, Håkanson R, Sundler F. Duodenal endocrine cells in adult coeliac disease. Gut 1979: 20:547-52.

${ }^{31}$ Kumar P, O'Donoughue DP, Lancaster-Smith M. Cellular changes in the jejunal mucosa following the reintroduction of gluten in treated coeliac disease. In: Pepys J, Edwards $\mathrm{AM}$, eds. The mast cell-its role in health and disease. Tunbridge Wells: Pitman Medical Publishing, 1979:647-56.

${ }^{32} \mathrm{Håkanson} \mathrm{R}, \mathrm{O}$ man $\mathrm{Ch}$, Sjöberg NO, Sporrong B. Amine mechanisms in enterochromaffin and enterocromaffin-like cells of gastric mucosa in various mammals. Histochemie 1970; 21:189-200.

${ }^{33}$ Nilsson G, Pernow B, Fischer GH, Folkers K. Presence of substance P-like immunoreactivity in plasma from man and dog. Acta Physiol Scand 1975; 94:542-4. 